UDC: $616.12-008.4$

\title{
ANGINA PECTORIS AND MYOCARDIAL ISCHEMIA IN THE ABSENCE OF OBSTRUCTIVE CORONARY ARTERY DISEASE: CLINICAL CASE
}

\author{
Marina Karavanova, Natalia Lisova, Marina Shevchuk \\ V. N. Karazin Kharkiv National University, 6 Svobody Sq., Kharkiv, 61022, Ukraine, \\ e-mail: med@karazin.ua
}

Our clinical case shows patient with worsening clinical signs of angina without obstructive lesions of coronary artery which requires further control. Recommendations for lifestyle modification as well as further treatment tactics are described.

KEY WORDS: Cardiac syndrome X, angina, ischemia, microvascular disfunctional

\section{СТЕНОКАРДІЯ ТА ІШЕМІЯ МІОКАРДУ ЗА ВІДСУТНОСТІ ОБСТРУКТИВНОЇ ХВОРОБИ КОРОНАРНИХ АРТЕРІЙ: КЛІНІЧНИЙ ВИПАДОК}

Караванова М. М., Лісова Н. О., Шевчук М. І.

Харківський національний університет імені В. Н. Каразіна, пл. Свободи, 6, м. Харків, 61022, Україна

Наш клінічний випадок свідчить про погіршення клінічних ознак стенокардії без обструктивних уражень коронарної артерії, що вимагає подальшого контролю. Описані рекомендації з модифікації способу життя, а також подальша тактика лікування.

КЛЮЧОВІ СЛОВА: кардіальний синдром Х, ішемія, мікроваскулярна дисфункція

\section{СТЕНОКАРДИЯ И ИШЕМИЯ МИОКАРДА ПРИ ОТСУТСТВИИ ОБСТРУКТИВНОЙ БОЛЕЗНИ КОРОНАРНЫХ АРТЕРИЙ: КЛИНИЧЕСКИЙ СЛУЧАЙ}

Караванова М. Н., Лесовая Н. А., Шевчук М. И.

Харьковский национальный университет имени В. Н. Каразина, пл. Свободы, 6, г. Харьков, 61022, Украина

Наш клинический случай показывает пациента с ухудшением клинических признаков стенокардии без обструктивных поражений коронарной артерии, что требует дальнейшего контроля. Описаны рекомендации по модификации образа жизни, а также дальнейшая тактика лечения.

КЛЮЧЕВЫЕ СЛОВА: кардиальный синдром Х, ишемия, микроваскулярная дисфункция

\section{INTRODUCTION}

Cardiac syndrome X (CSX, microvascular angina) is a pathological condition characterized by the presence of signs of myocardial ischemia (typical angina-like chest pain with evidence of myocardial ischemia: ST segment depression $\geq 1.5 \mathrm{~mm}[0.15 \mathrm{mV}]$ for more than 1 minute, during 48-hour ECG monitoring) in the absence of flow-limiting stenosis on coronary angiography and spasm of the epicardial coronary arteries during coronary angiography. The cost of case management of patients with chest pain and no obstructive CAD is not cheap as a result of challenges in diagnosis and treatment. [1-2]. Most patients with cardiac syndrome $\mathrm{X}$ are postmenopausal women [3-5]. However, the «female-pattern» terminology may soon be irrelevant [6]. CSX is likely to be multifactorial in these patients and 
it is conceivable that risk factors such as hypertension, hypercholesterolemia, diabetes mellitus and smoking can contribute to its development. Additional factors such as abnormal pain perception may contribute to the pathogenesis of chest pain in patients with angina pectoris and normal coronary angiograms [7].

\section{CLINICAL CASE}

The patient C., a man born in 1959 , was admitted to the clinical base of internal medicine department in Railway Clinical Hospital № 1 of «HC» JSC «Ukrzaliznytsia» in December, 11.10.17 with complaints of pressing pain behind the sternum radiating to the back with moderate severity of physical exertion, not relieved by nitro-glycerine, shortness of breath when rising to the 3rd floor, periodic numbness of the extremities, high blood pressure periodically to $150 / 90 \mathrm{~mm} \mathrm{Hg}$.

\section{ANAMNESIS MORBI}

In May 2017, patient was admitted at hospital for treatment of arterial hypertension, and from that time the pressing pain behind the sternum began to disturb. In June 2017, patient was hospitalized at The Endocrinology department for treatment of diabetes mellitus. There was performed ECG recording, ischemia was detected in the form of ST-segment depression; treadmill test was positive (ischemia detected). It was recommended a diet and patient received bisoprolol $5 \mathrm{mg} 1$ time per day, valsartan $40 \mathrm{mg} 1$ time per day in the morning, which he is taking now. Regarding the treatment of diabetes, patient takes glibenclamide $5 \mathrm{mg}$ in the morning before breakfast. However, after the treatment, there was no positive dynamics in the patient's condition. Currently, general condition of the patient is worsening during the last 3 weeks in the form of aggravation of the above complaints.

\section{ANAMNESIS VITAE}

1989 - appendectomy, 2000 - hymorotomy, since 2006 - diabetes mellitus type II, since 2011 - arterial hypertension. Ex-smoker - for 40 years until May 2017, 1 pack per day). Family history: mother and father - have high blood pressure. Infections, injuries, tuberculosis, sexually transmitted diseases were denied. Allergic history is not burdened.

\section{OBJECTIVE EXAMINATION}

General condition is satisfactory; consciousness is clear, emotionally stable. Height $-1.75 \mathrm{~m}$, weight $-83 \mathrm{~kg}$, BMI $27.13 \mathrm{~kg} / \mathrm{m}^{2}$ (overweight $=25.1-30 \mathrm{~kg} / \mathrm{m}^{2}$ ).

Skin is pale-pink, without any scars. There is symmetrical oedema of the lower extremities, up to the middle third of the leg, aggravated in the evening, not passing after a night rest. Peripheral lymph nodes are not palpable, on palpation of the thyroid gland painless. Signs of eyelid retraction, periorbital oedema, proptosis are absent.

Respiratory system: on percussion - normal percussion sound above both lungs, on auscultation- symmetrical decreased vesicular breathing. $\mathrm{RR}=20 / \mathrm{min}$.

Cardiovascular system: heart borders extended to the left on $2 \mathrm{~cm}$ of midclavicular line, HR $=70 \mathrm{bpm}$, regular. $\mathrm{Ps}=70 \mathrm{bpm}$. No pulse deficiency. Auscultation of the heart heart sounds heart tones are rhythmic, clear. Blood pressure $(\mathrm{BP})$ dextr $=145 / 88 \mathrm{~mm} \mathrm{Hg}, \mathrm{BP}$ $\sin =140 / 86 \mathrm{~mm} \mathrm{Hg}$, (on the background of antihypertensive therapy).

Gastrointestinal system: abdomen is symmetrical, soft, painless, no discrepancies of the abdominal muscles. No visible peristalsis. Liver edge is smooth, painless, palpated $1.5 \mathrm{~cm}$ below the costal arch. Spleen and pancreas are not palpable.

Pasternatskiy sign is positive on the right. Urination is free, painless.

\section{LABORATORY AND INSTRUMENTAL TESTS}

Tests were conducted according to the Protocol approved by order of the Ministry of Health of Ukraine from 02.03.16 No. 152: assessment of the pre-test probability of stable coronary artery disease (CAD), complete blood count, urinalysis, biochemical analysis of blood (potassium, sodium, creatinine, GFR, AlAT, AsAT), lipidogram (total cholesterol, TG, lowdensity lipoprotein; HDL, high-density lipoprotein), glucose, HbA1c, 12-lead Electrocardiography, echocardiography, treadmill and/or bicycle ergometer (bike) exercise tests, coronary angiography, abdominal ultrasound (additional), X-Ray (additional).

RESULTS OF LABORATORY AND INSTRUMENTAL DIAGNOSIS

Assessment of the pre-test probability of stable CAD: corresponds to medium to high 
pretest probability of $66-85 \%$, non-invasive functional tests with visualization are recommended to confirm the diagnosis.

Complete blood count: normal.

Urinalysis: normal.

Biochemical analysis: all parameters within the normal range.

Fasting glucose test: $8 \mathrm{mmol} / \mathrm{l}$.

HbAlc: $6.53 \%$ (N 4.8-5.9\%).

Lipidogram: total cholesterol $6 \mathrm{mmol} / \mathrm{l}$, TG $2.3 \mathrm{mmol} / 1$.

ECG: HR 79 bpm. Depression of the ST segment > $1 \mathrm{~mm}$ in leads II, V4-V5, regional disturbances of ventricular contractility. Diffuse disturbances of repolarization processes, signs of left ventricular hypertrophy ( $\mathrm{LVH})$.

Echocardiography: Sclerotic changes of aortic walls, aortic and mitral valves. Dilatation of the ascending aorta. Dilatation of the left atrium. Left ventricular hypertrophy. Mitral regurgitation of the 1nd degree. EF $51 \%-44$ (N: 55-78\%).

Abdominal ultrasound: Diffuse changes in the parenchyma of the liver and pancreas without enlargement of them. Thickening of the gallbladder wall. Congestion bile in gallbladder. Right-sided hydrocalycosis. Cyst of the right kidney. Split of pyramid-shaped lobes the left kidney. Kidney microcalculus.

Angiography: Right type of coronary blood flow. Moderate of coronary tortuosity on the coronary blood flow. The left coronary artery the trunk is not changed, circumflex and left anterior descending coronary artery and its branches is not visible angiographic signs of atherosclerotic lesion. The right coronary artery - no plaque was detected.

\section{CLINICAL DIAGNOSIS}

Essential arterial hypertension stage II, 1 grade. Hypertensive heart (LVH). The risk is moderate. Ischemic heart disease: microvascular angina (positive stress echoCG 20.06.17). Coronary arteries without obstructive lesions (angiography 12.10.17.). Combined dyslipidaemia. Heart failure with preserved ejection fraction II A stage, NYHA II.

Co-morbidity: Diabetes mellitus type 2, moderate severity, compensation.

\section{OUR RECOMMENDED TREATMENT ACCORDING LAST GUIDELINES}

Non-pharmacologic:

$\checkmark$ Lifestyle modification: adequate physical activity (aerobic exercise for $30 \mathrm{~min} 3$ or more times a week), body weight correction (BMI $18.5-24.9 \mathrm{~kg} / \mathrm{m}$, waist circumference less than $102 \mathrm{~cm}$ in men)

$\checkmark$ Dietary recommendations

Mediterranean diet:

- decrease sodium intake to 4-6 g/day;

- adequate fluid intake;

- saturated fatty acids should provide less than $10 \%$ of the total energy value of the daily diet, they should be replaced by polyunsaturated fatty acids;

$-200 \mathrm{~g}$ of fruit per day (2-3 times);

$-200 \mathrm{~g}$ of vegetables per day (2-3 times);

- fish, at least 2 times per week, one of the times - sea fish;

- 30-40 g of dietary fiber per day in the form of whole grain products, vegetables and fruits.

$\checkmark$ BP monitoring (target level less than 140/90 mm Hg).

$\checkmark \quad$ Glycemia control.

Treatment strategy:

$\checkmark$ Perindopril $5 \mathrm{mg}$ once daily continuously, under BP control

$\checkmark \quad$ Indapamide $2.5 \mathrm{mg}$ once daily continuously

$\checkmark \quad$ Acetylsalicylic acid $75 \mathrm{mg}$ once daily continuously

$\checkmark$ Rosuvastatin $40 \mathrm{mg} 1$ time in the evening for 4 weeks. Control AlAT, AsAT after 4 weeks

$\checkmark \quad$ Trimetazidine $60 \mathrm{mg}$ per day for 3 months

$\checkmark \quad$ Kvamatel (famotidine) $20 \mathrm{mg} 2$ times a day for 14 days

$\checkmark$ Omega-3 polyunsaturated fatty acids $1000 \mathrm{mg}$ daily for 3 months

$\checkmark \quad$ Medical therapy of diabetes

\section{PROGNOSIS}

Although prognosis is good regarding survival, patients with cardiac syndrome $\mathrm{X}$ have an impaired quality of life.

In a recent survey conducted in four large European countries, women reported more severe angina, a higher number of angina attacks per month, and more frequently accompanying symptoms (dyspnoea, arrhythmias/tachycardia), than men. Atypical symptoms were more common for women as well [8].

\section{PREVENTION}

Secondary prevention include lifestyle modification; good blood pressure control, 
decrease sodium intake, lipid lowering diet, aerobic non strenuous exercises; control of fluid balance and check up for decompensation of heart failure; control of compliance to our medical recommendations.

\section{DISCUSSION}

The mechanisms underlying angina pectoris in essential arterial hypertension patents without obstructive coronary artery disease are still largely unknown, but such association doesn't rarely occurs [9-11]. Furthermore, hypertensive patents have a higher likelihood of presenting with features of the metabolic syndrome, e.g., hypertension, dyslipidaemia, obesity and insulin resistance, compared with the general population, which makes the diagnosis and treatment of such comorbid cases more complex and multicomponent [12-13]. Insulin resistance, therefore, may represent an important mechanism for vascular dysfunction in this setting [14-16]. Moreover, cardiac syndrome $\mathrm{X}$ is now recognized as a condition that can cause a significant morbidity and increases the risk for $\mathrm{CV}$ events [1]

Evidence-based guidelines for treating CSX are still lacking as well as optimal methods of identification of CMD patients although research in this direction continues [1, 17-23]. Therefore, the presentation and study of cases of successful management of patients with this pathology remains relevant.

Our clinical case shows patient with worsening clinical signs of angina without obstructive lesions of coronary artery which requires further control with all the necessary diagnostic methods. This article describes the subsequent management of our patient, which includes both non-drug methods of treatment that cannot be neglected, based on the comorbidity of the disease and the material burden on the patient in general, and medication management.

As a result of our research, our patient needed further correction of the treatment of $\mathrm{AH}$ and more accurate diagnosis (and treatment) of angina pectoris and first of all, modification of the lifestyle and reconsideration of the regularity of taking medicines.

\section{CONCLUSION}

1. This case is interesting in the development of decompensation (oedema of the lower extremities, reduced tolerance to stress) in a patient with cardiac syndrome $\mathrm{X}$.

2. Management of patents with angina and evidence of myocardial schema on stress testing without obstructive coronary artery disease by angiography (previously referred to as cardiac syndrome $\mathrm{X}$, or CSX) is a challenge.

3. Key points for the clinician include recognition of schema and deployment of guideline-endorsed therapy for angina and reduction of cardiac risk factors.

4. Systemic hypertension is often associated with microvascular angina. Several pathogenic mechanisms have been identified which represent suitable targets for treatment. Microvascular dysfunction needs to be investigated (and treated if present) in patents with systemic hypertension, angina and angiographically normal coronary arteries.

\section{REFERENCES}

1. Agrawal S., Mehta P. K., Merz C. N. B. Cardiac syndrome X: update // Heart failure clinics. - 2016. - T. 12. - No. 1. - p. 141-156.

2. Kret M. Cardiac syndrome X--epidemiology, diagnostics, ethiopatoghenesis, prognosis, treatment and latest guidelines // Przeglad lekarski. - 2016. - T. 73. - No. 1. - p. 40-45.

3. Cadeddu C. et al. Altered transmural contractility in postmenopausal women affected by cardiac syndrome X //Journal of the American Society of Echocardiography. - 2014. - T. 27. - No. 2. - p. 208-214.

4. Lansky A. J., Pietras C. Coronary Microvascular Dysfunction: Does Sex Matter? - 2015.

5. Chou A. Y., Saw J. Basis for sex-specific expression of Takotsubo cardiomyopathy, cardiac syndrome X, and spontaneous coronary artery dissection // Canadian Journal of Cardiology. - 2014. - T. 30. - No. 7. p. 738-746.

6. Nelson M. D. et al. Coronary microvascular dysfunction and heart failure with preserved ejection fraction as female-pattern cardiovascular disease: the chicken or the egg? // European heart journal. - 2018.

7. Pepine C. J., Merz C. N. B., Johnson B. D. Reply: Association Between Migraine Headache and Cardiac Syndrome X // Journal of the American College of Cardiology. - 2016. - T. 67. - No. 17. - P. 2088. 
8. Zuchi C., Tritto I., Ambrosio G. Microvascular angina: Are all women created equal? // International Journal of Cardiology. - 2018.

9. Mahfouz R. A. et al. Association of morning blood pressure surge with carotid intima-media thickness and cardiac dysfunction in patients with cardiac syndrome-X // Blood pressure. - 2018. - P. 1-7.

10. Marinescu M. A. et al. Coronary microvascular dysfunction, microvascular angina, and treatment strategies // JACC: Cardiovascular Imaging. - 2015. - T. 8. - No. 2. - P. 210-220.

11. Bairey Merz C. N. et al. Ischemia and No Obstructive Coronary Artery Disease (INOCA) Developing Evidence-Based Therapies and Research Agenda for the Next Decade // Circulation. - 2017. - T. 135. No. 11. - P. 1075-1092.

12. Khaliq A. et al. Relationships between components of metabolic syndrome and coronary intravascular ultrasound atherosclerosis measures in women without obstructive coronary artery disease: the NHLBISponsored Women's Ischemia Syndrome Evaluation Study // Cardiovascular endocrinology. - 2015. T. 4. - No. 2. - P. 45.

13. O'neill S., O'driscoll L. Metabolic syndrome: a closer look at the growing epidemic and its associated pathologies // Obesity reviews. - 2015. - T. 16. - No. 1. - P. 1-12.

14. Prieto D., Contreras C., Sánchez A. Endothelial dysfunction, obesity and insulin resistance // Current vascular pharmacology. - 2014. - T. 12. - No. 3. - P. 412-426.

15. Patel T. P. et al. Insulin resistance: an additional risk factor in the pathogenesis of cardiovascular disease in type 2 diabetes // Heart failure reviews. - 2016. - T. 21. - No. 1. - P. 11-23.

16. Laakso M., Kuusisto J. Insulin resistance and hyperglycaemia in cardiovascular disease development // Nature Reviews Endocrinology. - 2014. - T. 10. - No. 5. - P. 293.

17. Thomson L. E. J. et al. Cardiac magnetic resonance myocardial perfusion reserve index is reduced in women with coronary microvascular dysfunction: a National Heart, Lung, and Blood Institute-sponsored study from the Women's Ischemia Syndrome Evaluation // Circulation: Cardiovascular Imaging. - 2015. T. 8. - No. 4. - P. e002481.

18. Zhang X. et al. Effects of combination of statin and calcium channel blocker in patients with cardiac syndrome X // Coronary artery disease. - 2014. - T. 25. - No. 1. - P. 40-44.

19. Zaya M., Mehta P. K., Merz C. N. B. Provocative testing for coronary reactivity and spasm // Journal of the American College of Cardiology. - 2014. - T. 63. - No. 2. - P. 103-109.

20. Cocco G., Jerie P. Angina pectoris in patients without flow-limiting coronary artery disease (cardiac syndrome X). A forest of a variety of trees // Cardiology journal. - 2015. - T. 22. - No. 6. - P. 605-612.

21. Szot W. et al. Cardiac rehabilitation: a good measure to improve quality of life in peri-and postmenopausal women with microvascular angina // Annals of Agricultural and Environmental Medicine. - 2015. - T. 22. - No. 2.

22. Crea F., Lanza G. A. Treatment of microvascular angina: the need for precision medicine. -2016.

23. Park J. J., Park S. J., Choi D. J. Microvascular angina: angina that predominantly affects women // The Korean journal of internal medicine. - 2015. - T. 30. - No. 2. - P. 140. 